\title{
ІНТЕГРОВАНИЙ ПІДХІД ДО ФОРМУВАННЯ МОДЕЛІ ПРИЙНЯТТЯ УПРАВЛІНСЬКИХ РІШЕНЬ НА ПІДПРИЕМСТВІ
}

\section{INTEGRATED APPROACH TO FORMATION OF THE MODEL OF MANAGEMENT DECISIONS AT THE ENTERPRISE}

\author{
Левицький Віктор Володимирович \\ кандидат економічних наук, доцент, \\ Волинський національний університет імені Лесі Українки \\ ORCID: https://orcid.org/0000-0001-8695-9690 \\ Levytskyi Viktor \\ Lesya Ukrainka Volyn National University
}

\begin{abstract}
Стаття присвячена актуальним питанням сутності та складовим інтегрованого підходу до фрормування моделі прийняття управлінських рішень на підприємстві. Проаналізовано завдання транссормації теоретикометодологічних положень фрормування процесу управління, визначено головний інструментарій вирішення управлінських завдань на основі фрормування оптимальних результатів практичних рішень із використанням реструктуризації системи підтримки та ухвалення управлінських рішень з позицій інтегрованого підходу за допомогою адекватного відображення його впливу на процес управління. Сфрормовано основні принципи та модель інтегрованого підходу до процесу прийняття управлінських рішень на підприємстві, що базується на врахуванні впливу усіх фракторів внутрішнього та зовнішнього середовища як на керівника так і на підприємство.
\end{abstract}

Ключові слова: управління, підприємство, управлінське рішення, інтегрований підхід, модель прийняття управлінських рішень, інтегрований підхід до прийняття управлінських рішень.

Статья посвящена актуальным вопросам сущности и составляющим интегрированного подхода к фрормированию модели управления управленческих решений на предприятии. Проанализировано особенности трансфрормации теоретических и методологических положений фрормирования процесса управления, определен главный инструментарий решения управленческих заданий на основе формирования оптимальных результатов практических решений с использованием реструктуризации системы поддержки и принятия управленческих решений с позиций интегрированного подхода с помощью адекватного отражения влияния на процесс управления. Сформированы основные принципы и модель интегрированного подхода к процессу принятия управленческих решений на предприятии, которое базируется на учете влияния всех фракторов внутренней и внешней среды как на руководителя так и на предприятие.

Ключевые слова: управление, предприятие, управленческое решение, интегрированный подход, модель принятия управленческих решений, интегрированный подход до принятия управленческих решений.

The article is devoted to topical issues of the essence and components of an integrated approach to the formation of a model of management decisions in the enterprise. The main features of the integrated approach to the enterprise management system are determined and its place in the management system and components are specified. Provisions and principles of the integrated approach to acceptance of the administrative decisions providing the correct and optimum system of management of activity of the enterprise are offered. The difference between the management process and local management processes is determined and it is offered to carry to local management processes: management process from moral positions; emotional management process; volitional process of management. The study also outlines the task of transforming the theoretical and methodological provisions of the management process and tools for solving management problems based on the formation of optimal results of practical decisions using the restructuring of support systems and management decisions from the standpoint of an integrated approach by adequately reflecting the impact on management. In addition, we noted that the management process in most cases consists of logical reasoning and action, and at the stage of development and decision-making is a procedure to prove or disprove the correctness of decisions. The result of the research is de- 
termined, which consists in developing a model of the managerial decision-making process at the enterprise, which describes the formation of decisions by the head-manager in thoughts, emotions, feelings and their interaction and influence on the management process of various cultural, socio-political, demographic and other factors. The article also takes into account the full range of factors of action at the time of management decision in the enterprise by the manager using an integrated approach model, which should be based on the impact of all internal and external factors on the manager and the company with their preliminary analysis to form effective prerequisites for making management decisions and taking into account their further impact on the strategic development of the enterprise in conditions of uncertainty.

Keywords: management, enterprise, management decision, integrated approach, management decision model, integrated approach to management decision making.

Постановка проблеми. Однією з найважливіших умов існування та подальшого розвитку сучасного суспільства - $€$ масштабна модернізація існуючих процесів управління в усіх сорерах економіки. Для їі реалізації нам знадобиться принципова інша якість управління підприємствами, що базується на основі розвитку сучасного управління у вигляді специфічного виду діяльності і зростання його ролі як закономірного вираження суспільно-історичного прогресу. Зазначимо, що комплексним вивченням завдань, методів та напрямів розробки сучасних систем управління підприємства разом 3 соціологами, економістами, інженерами займаються також психологи, математики, юристи, фрілософи та інші науковці, оскільки саме дисеренціація областей науки у сорері менеджменту може змінити наявні підходи до системи прийняття управлінських рішень. Визнаючи досягнення в області управління, зазначимо, що реалії розвитку економіки свідчать про існування проблем управління щодо системи прийняття управлінського рішення на підприємстві. Особливо це стосується ухвалення багатоваріантних, взаємопов'язаних управлінських рішень, що мають місце при всебічному розгляді багатьох різних видів фракторів. Наявність проблем управління показує відсутність та необхідність комплексного, міждисциплінарного аналізу із одночасним формуванням моделі прийняття управлінських рішень, що об'єднує культурні, психологічні та інші аспекти процесу управління.

Аналіз останніх досліджень та публікацій. Аналіз розвитку теорії й практики управління показує, що проблеми управління займали значне місце в працях вітчизняних та закордонних вчених.

Розробці питань управління присвячені праці: І. Ансофрфра, М. Бутко, Д. Гвішіані, В. Джуха, М. Йохна, О. Кузьміна, Л. Ліпич, Г. Осовської, Л. Скібіцької, В. Стадника, Ф. Хміля [1; 3; 5-11].

Діяльність підприємств у різних аспектах вивчена в працях: У. Бреддіка, І. Кривов'юзюка, О. Малікова, С. Соколіцина, М. Слодкевича [4].
Про застосування інтеграції, інтеграційного підходу в менеджменті, при мотивації діяльності працівників відзначається в роботах: Г. Кіндрацької, О. Кузьміна, О. Мельник, Г. Осовської, Л. Скібіцької, В. Стаднка, Ф. Хміля [2-3; 6-7; 9-11].

Виділення невирішених раніше частин загальної проблеми. Проте, як показує аналіз роботи підприємств, проблеми виникають внаслідок помилок у процесах управління, при ухваленні рішень керівниками, що характеризує людський та інші фрактори, що впливають на нього: психологічні, культурні, політичні, економічні. Досліджуючи особливості існуючих теоретичних й практичних методів при розробці планів розвитку підприємства, що мають численні кількісні й нечіткі показники, не опрацьована дія на них варіантів оперативних рішень в обмежуючих умовах якісного і кількісного характеру та не враховується вплив випадкових сракторів, що визначає актуальність дослідження інтегрованого підходу до фрормування моделі прийняття управлінських рішень на підприємстві.

Формулювання цілей статті (постановка завдання). Основною ціллю статті $\epsilon$ розвиток теоретичних засад управління, що полягає у формуванні моделі прийняття і ухвалення управлінських рішень для підприємств з позицій інтегрованого підходу.

Виклад основного матеріалу дослідження. Аналізування теоретичних засадй практики управління показує, що при великій кількості досліджень за проблемами управління й різноманітті точок зору на їх вирішення в науковій теорії, орієнтованій на ухвалення управлінських рішень, відсутня єдина модель, що інтегрує раціональні, психологічні, соціальні, культурні та інші складові процесу управління. Наслідком вищезазначених проблем $€$ необхідність розробки в даному напрямі концепції фрормування процесу управління на основі інтегрованого підходу до прийняття управлінського рішення на підприємстві. Варто зазначити, що інтеграція (від латинського «integer»цілий) - це об'єднання в ціле якихось частин, 
елементів. У працях науковців інтегрований підхід до менеджменту розглядається як підхід, націлений на дослідження й посилення взаємозв'язків між окремими підсистемами та елементами системи менеджменту, стадіями життєвого циклу об'єкту управління, рівнями управління по-вертикалі, між суб'єктами управління по-горизонталі [6, с. 345]. Крім того, інтеграцію представляють як об'єднання економічних суб'єктів, поглиблення й розширення їх виробничо-технічної взаємодії, спільне використання ресурсів, об'єднання капіталів, створення один одному сприятливих умов здійснення економічної діяльності [3, с. 111].

На нашу думку, інтегрований підхід щодо формування процесу прийняття управлінських рішень на підприємстві має базуватися на наступних основних положеннях:

- процес розробки, прийняття і реалізації рішень здійснюється та втілюється в думках, емоціях, почуттях;

- процес управління (інтегроване ціле) розподіляється на локальні процеси (підсистеми) на основі досвіду, логічного мислення, переживань й вираження чуттєво-емоційних стосунків, кожен з яких у свою чергу ділиться на частини, кінець кінцем, на елементи управління;

- емоції, почуття, потреби, мотиви, способи мислення осіб, що приймають рішення, взаємодіють та взаємозв'язані один з одним й презентують визначену систему - як результат формують рішення;

- в процесі управління диференційовано розглядаються й використовуються індивідуально для кожного його учасника елементи підсистем культури, психології, логіки та розвитку ситуації.

Крім вище зазначених положень, на нашу думку, локальні процеси управління можуть здійснюватись за наступними принципами:

- постійна присутність особистих якостей в учасників управлінської діяльності (керівників та їх оточення);

- існування потреб, мотивів, емоцій, почуттів у свідомості незалежно від розумових процесів;

- вплив особистих якостей на сприйняття інорормації, на розробку й ухвалення управлінських рішень, на їх організацію та виконання;

- виділення управлінських дій із характерною особливістю (мотиваційною, моральною, логічною, емоційною, вольовою);

- інтеграція приватних емоцій, почуттів, потреб, мотивів, логічних фрорм, способів зв'язку елементів, думок в єдине ціле;

- орієнтація на загальнолюдські моральні цінності при срормуванні процесу прийняття управлінського рішення на підставі диференційованого розгляду індивідуальних якостей кожного учасника процесу управління.

Зазначимо, що процес управління та локальні процеси управління - це не абсолютно незалежні процеси, вони співвідносяться як ціле та його частини. Визначення «збір та обробка інформації», «ранжування проблем, завдань», «моральний», «логічний», «емоційний», «вольовий» використовуються лише для того, щоб показати наявність в діях певної компоненти [8; 10-11]. До локальних процесів управління у нашому дослідженні варто віднести:

- процес управління з моральних позицій, що $€$ тою частиною управлінського процесу, дії якого здійснюються через призму моральних рис керівника та з урахуванням індивідуальних моральних якостей осіб, що беруть участь в управлінні;

- процеси управління, здійснювані на емоційному рівні - це усі ті процеси, що дозволяють виділити 3 поведінки учасника управлінського процесу емоційну складову та пов'язані з ним дії;

- вольовий процес управління - включає вольові дії як різновид дій учасників управлінського процесу. При прояві волі учасник управлінського процесу свідомо та навмисно планує свої дії відповідно до власних бажань, поставлених цілей, з переживанням та почуттям обов'язку.

На нашу думку, процес управління у більшості випадків складається 3 логічних міркувань й дій, а на етапі розробки й ухвалення рішень здійснюється процедура доказу або спростування правильності рішень, що приймаються. Крім того, на етапі контролю управлінських рішень, реалізується процедура виявлення причин відхилень, безпосереднього спростування або доказу правильності виконаних дій, раніше прийнятих рішень. У складних умовах господарювання причиною відхилення може бути цілий комплекс обставин. Встановлення істинності зв'язку між відхиленнями та версіями причин, тобто пошук першопричини, менеджер здійснює на основі встановлення логічного зв'язку між отриманими даними, відомостями про відхилення й причини. Використані при даному процесі методи встановлення причинних зв'язків за своєю логічною структурою відносяться до складних міркувань, в яких індуктивні узагальнення фрормуються за участю дедуктивних висновків [9, с. 128].

У дослідженні варто також зрозуміти, що при пошуку причин відхилення в критичних 
ситуаціях, використовуючи взаємозв'язок індукції та дедукції, необхідно забезпечувати логічну спроможність думок, а процес ухвалення рішень у бінарній (простій) ситуації здійснюється безперечно, несуперечливий, послідовний та обґрунтований із застосуванням логічного закону, за умови дотримання законів тотожностей й протиріч.

Саме тому, ми пропонуємо розробити модель процесу прийняття управлінського рішення на підприємстві, що описує фрормування керівником-менеджером рішень в думках, емоціях, почуттях та вплив на управлінський процес різного роду фракторів культурного, соціально-політичного, демографрічного та іншого характеру [4-5].

На нашу думку, формування процесу управління розглядається як інтеграція думок, відображень, почуттів та інших компонентів процесу із урахуванням різного роду фракторів впливу. Ми пропонуємо модель процесу управління із позицій інтегрованого підходу прийняття управлінських рішень на підприємстві (див. рис. 1).

Враховуючи передусім критичний аналіз теоретичного матеріалу, який орієнтований на ухвалення рішень, нами виявлено, що в наявних моделях немає логічного опису характеру здійснення зв'язку управлінських дій та впливу на процес управління культурних, соці- ально-політичних та інших, як кількісних, так і нечітких, фракторів, при інтегрованій дії на ухвалення рішень приватних емоцій, почуттів, потреб, мотивів, логічних фрорм, законів, способів зв'язку, думок.

Сприйняття та передача управлінської інсрормації завжди в тій чи іншій мірі залежать від довкілля, особистих якостей учасників комунікаційного процесу, їх культури, психології, досвіду, логіки мислення в процесі фрормування управлінського рішення. Свідомо сприйняти її - означає подумки віднести якісь дані, відомості, значення слів, виразів обличчя, очей, дії незалежно від часу використання інорормації до певного завдання, ситуації, мети. У момент усвідомлення значущості інорормації керівник здійснює процес мислення, чуттєвоемоційне переживання [2, с. 226].

Крім того, в процесі управління мають місце рішення на основі досвіду, уяви й логічного мислення. Цінність уяви полягає в тому, що вона дозволяє керівникові прийняти рішення навіть за відсутності повної інсрормації щодо проблеми. Творчий процес, спрямований на вирішення проблем управління, багато в чому залежить від досвіду керівника, а мислення тісно пов'язане з уявою та виникає при появі проблемної ситуації, коли необхідно прийняти правильне (збалансоване) рішення. Рішення, прийняті керівником на основі

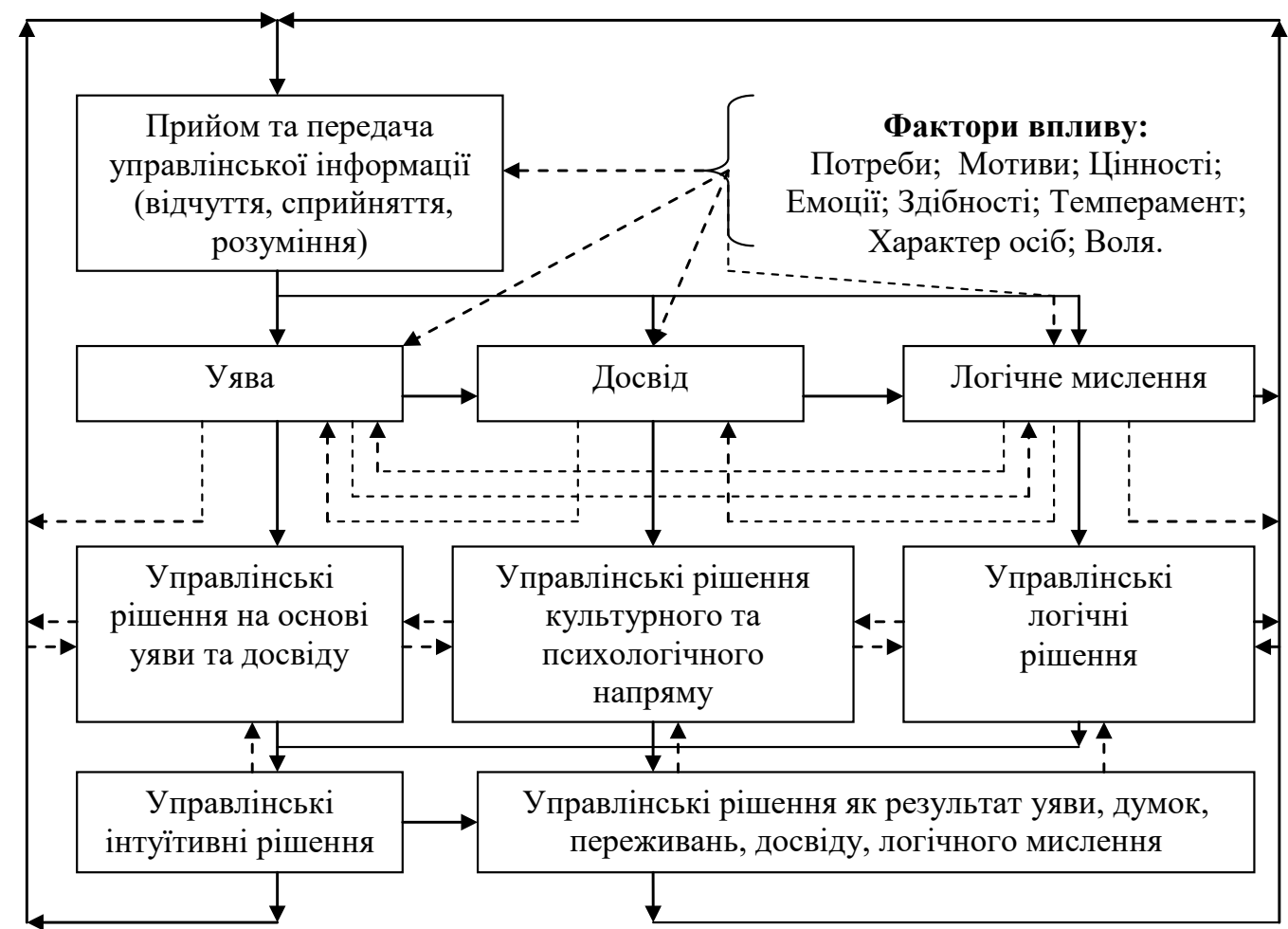

Рис. 1. Модель інтегрованого процесу прийняття управлінського рішення на підприємстві 
понять, суджень, висновків, логічних методів й законів, з використанням доказів, варто вважати логічними рішеннями [1, с. 179].

Види висновків, за допомогою яких учасники управлінського процесу здійснюють аналіз й синтез фактів, відомостей, бувають різними та залежать не лише від самих фрактів, умов, але й від психології, рівня культури осіб, що сприймають і аналізують інсрормацію. Якщо керівник або інша особа використовує систему загальних знань, його висновки реалізуються у формі дедуктивних висновків. Якщо в процесі управління використовуються знання про одиничні випадки й фракти, то будують висновки аналогічно, порівнюючи даний варіант рішення з прийнятим попередньо аналогічним то аналіз здійснюється у формі індукції. Відповідно, чим більший накопичений досвід та знання, тим більше проводиться аналогій, повніші емпіричні узагальнення та уява керівника щодо фрормування правильного управлінського рішення [9, с. 89].

Зазначимо, що усе з чим стикається керівник у своїй діяльності, викликає у нього певні стосунки, ті або інші почуття. Практично в кожній ситуації управлінська діяльність керівника пов'язана з ухваленням таких рішень, які розкривають його культурні особливості та культуру осіб, що контактують з ним. Емоційний стан також впливає на ухвалення рішень. Під впливом емоцій керівник може прийняти рішення, що суперечить логіці. Сучасні менеджери стверджують, що емоції можуть викликати у свідомості процес, абсолютно неза- лежний від раціональних процесів. Саме тому, головним питанням запропонованої нами моделі прийняття управлінських рішень на підприємстві, можна зазначити у вигляді: що лежить в основі ухвалення рішення: логіка або почуття, емоції чи досвід - важко визначити. Логічно припустити, що справедливим $€$ усі елементи вирішення проблем та їх комплексна взаємодія. Оскільки, почуття керівника можуть впливати й активізувати протікання процесу ухвалення рішення, а логіка може бути основою рішення. Крім того, на процеси ухвалення рішень роблять вплив потреби та бажання прискорити досягнення встановлених цілей розвитку діяльності підприємства.

Висновки та перспективи подальших досліджень. Отже, розроблені нами у статті положення, принципи та модель фрормування інтегрованого процесу прийняття управлінського рішення на підприємстві забезпечує вивчення динамічного характеру процесу управління, моделювання тимчасової залежності рішень, що приймаються, на етапі їх реалізації із урахуванням взаємодії й особливостей виробничої діяльності та впливу численних фракторів як на керівника так і на підприємство. Вони дозволяють фрормувати й здійснювати процес управління, приймати рішення, інтегруючи кількісні та якісні дані, критерії, варіанти рішень, розглядати управлінські процеси в динаміці та враховувати складні багатозмінні зв'язки, нелінійні залежності між змінними, випадковими величинами у перспективі.

\section{СПИСОК ВИКОРИСТАНИХ ДЖЕРЕЛ:}

1. Бутко М. П. Стратегічний менеджмент : навч. посіб. Київ : Центр учбової літератури, 2016. 376 с.

2. Кіндрацька Г. І. Стратегічний менеджмент : навч. посіб. Київ : Знання, 2006. 366 с.

3. Кузьмін О. Є., Мельник О. Г. Основи менеджменту : підручник. Київ : Академвидав, 2003. 416 с.

4. Кривов'язюк І. В. Підприємство в умовах ринку : навч. посіб. для студ. вищ. навч. закл. Київ : Кондор, 2009. $840 \mathrm{c}$.

5. Ліпич Л. Г., Морохова В. О., Московчук А. Т. Організація виробництва : навч. посіб. [для студ. вищ. навч. закл.]. Луцьк : РВВ ЛДТУ, 2002. 256 с.

6. Осовська Г. В., Осовський О.А. Менеджмент організацій : навч. посіб. Київ : Кондор, 2009. 854 с.

7. Осовська Г. В. Основи менеджменту : навч. посіб. Київ : Кондор, 2003. 556 с.

8. Подольчак Н. Ю. Стратегічний менеджмент : навч.-метод. посіб. Львів : Вид-во НУ «Львівська політехніка», 2016. 223 с.

9. Скібіцька Л. І., Скібіцький О. М. Менеджмент : навч. посіб. Київ : Центр учб. л-ри, 2007. 416 с.

10. Стадник В. В., Йохна М.А. Менеджмент : навч. посіб. Київ : Академвидав, 2003. 464 с.

11. Хміль Ф. І. Основи менеджменту : підручник. Київ : Академвидав, 2003. 608 с.

\section{REFERENCES:}

1. Butko, M. P. (2016). Stratehichnyi menedzhment [Strategic management]. Kyiv: Centr uchbovoji literatury. (in Ukrainian) 
2. Kindratska, H. I. (2006). Stratehichnyi menedzhment [Strategic management]. Kyiv: Znannya. (in Ukrainian)

3. Kuzmin, O. Ye., \& Melnyk, O. H. (2013). Osnovy menedzhmentu [Fundamentals of management]. Kyiv: Akademvydav. (in Ukrainian)

4. Kryvoviaziuk, I. V. (2009). Pidpryiemstvo v umovakh rynku [Enterprise in market conditions]. Kyiv: Kondor. (in Ukrainian)

5. Lipych, L. H., Morokhova, V. O., \& Moskovchuk, A. T. (2002). Orhanizatsiia vyrobnytstva [Organization of production]. Lutsk: RVV LDTU. (in Ukrainian)

6. Osovska, H. V., \& Osovskyi, O. A. (2009). Menedzhment orhanizatsii [Management of organizations]. Kyiv: Kondor. (in Ukrainian)

7. Osovska, H. V. (2003). Osnovy menedzhmentu [Fundamentals of management]. Kyiv: Kondor. (in Ukrainian)

8. Podolchak, N. Yu. (2006). Stratehichnyi menedzhment [Strategic management]. Lviv: NU «Lvivska politekhnika». (in Ukrainian)

9. Skibitska, L. I., \& Skibitskyi, O. M. (2006). Menedzhment [Management]. Kyiv: Tsentr uchb. I-ry. (in Ukrainian) 10. Stadnyk, V. V., \& Yokhna, M. A. (2006). Menedzhment [Management]. Kyiv: Akademvydav. (in Ukrainian)

11. Khmil, F. I. (2003). Osnovy menedzhmentu [Fundamentals of management]. Kyiv: Akademvydav. (in Ukrainian) 